\title{
Pengembangan Audio Visual Bahan Ajar Mikrobiologi Berbasis Penelitian Bakteri Lipolitik Untuk Mengukur Kemampuan Berpikir Kreatif

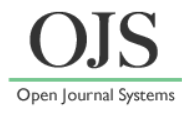

\author{
Emi Hartati ${ }^{1,2 *}$, Agus Sundaryono ${ }^{2}$, Sipriyadi $^{3}$ \\ ${ }^{1}$ SMPN 3 Bengkulu Tengah Provinsi Bengkulu \\ ${ }^{2}$ Pascasarjana Pendidikan IPA Universitas Bengkulu \\ ${ }^{3}$ Jurusan Biologi FMIPA Universitas Bengkulu \\ *Email: emihartati29@gmail.com
}

DOI: https://doi.org/10.33369/pendipa.v3i1.6920

\begin{abstract}
[Development of Visual Audio-Based Microbiology Research Materials for Lipolithic Bacteria to Measure The Ability of Creative Thinking]. The purpose of this research was to develop the design of audio visual teaching materials to measure the creative thinking ability of biology students of FMIPA University of Bengkulu, based on research of lipolytic bacteria degrading palm oil liquid waste. The development model used is the $4 D$ model (define, design, develop, disseminate). In the defining phase, an analysis of the depth of the material, from learning indicators in syllabus, units of lectures agenda and a great line of lesson plan. The analysis is also done by direct interviews to lecturers of microbiology subjects, and participate in learning activities both in the classroom and laboratory. The results of this material analysis serve as guidance in making the design of audio visual teaching materials. The next stage of activity is the design of the preparation of teaching materials developed from the existing learning syllabus. The design of audio visual teaching materials is carried out by feasibility measurement by media experts, IT experts and education practitioners. The results of the measurement of audio-visual material by media experts as $80 \%$, by IT experts as $91.2 \%$, and by education practitioners $75.2 \%$. The deployment stage was only tested on 72 students of Biology Strata one math and science faculty University of Bengkulu, to see the level of creative thinking ability. Measurements to the level of creative thinking ability of students obtained a value of $12.5 \%$ in the high category, $70.8 \%$ medium category, and $16.7 \%$ low category.
\end{abstract}

Keywords: Audio visual; Creative Thinking; 4 D Model

(Received August 13, 2018; Accepted January 12, 2019; Published February 25, 2019)

\section{ABSTRAK}

Tujuan penelitian ini adalah mengembangkan desain bahan ajar audio visual untuk mengukur kemampuan berpikir kreatif mahasiswa biologi Fakultas Matematika dan Ilmu Pengetahuan Alam Universitas Bengkulu, yang berbasis penelitian bakteri lipolitik pendegradasi limbah cair kelapa sawit. Model pengembangan yang digunakan yaitu model $4 D$ (define, design, develop, desseminate). Pada tahap pendefinisian dilakukan analisis terhadap kedalaman materi, dari indikator pembelajaran yang ada di silabus, satuan acara perkuliahan dan garis besar rencana pembelajaran. Analisis juga dilakukan dengan wawancara langsung kepada dosen pemangku mata kuliah mikrobiologi, dan ikut serta dalam kegiatan pembelajaran baik di kelas maupun praktikum di laboratorium. Hasil dari analisa materi ini dijadikan pedoman dalam membuat desain bahan ajar audio visual. Tahapan kegiatan selanjutnya adalah rancangan desain penyusunan bahan ajar yang dikembangkan dari silabus pembelajaran yang sudah ada. Desain bahan ajar audio visual dilakukan pengukuran kelayakan oleh ahli media, ahli IT dan praktisi pendidikan. Hasil pengukuran kelayakan bahan ajar audio visual oleh ahli media $80 \%$, oleh ahli IT $91,2 \%$, dan oleh praktisi pendidikan 75,2 \%. Tahap penyebaran hanya diuji cobakan pada 72 orang mahasiswa S-1 Biologi Fakultas Matematika dan Ilmu Pengetahuan Alam Universitas Bengkulu, untuk melihat tingkat kemampuan berpikir kreatifnya. Pengukuran terhadap tingkat kemampuan berpikir kreatif mahasiswa didapatkan nilai $12,5 \%$ dalam kategori tinggi, 70,8 \% kategori sedang, dan 16,7 \% kategori rendah.

Kata kunci : Audio visual; Berpikir kreatif; Model 4D. 


\section{PENDAHULUAN}

Proses pembelajaran di perguruan tinggi tidak sebatas memberikan mata kuliah, materi maupun konsep-konsep penting, namun juga harus memberikan pengalaman belajar (Hamzah, 2014). Pengalaman belajar dapat difasilitasi dengan penggunaan bahan ajar yang dapat mengarahkan mahasiswa tidak hanya pada perolehan konsep, tetapi juga pengembangan kemampuan berpikir kreatif.

Pembelajaran yang didasarkan pada hasil penelitian diharapkan dapat mewujudkan terlaksananya pembelajaran yang kontekstual, serta menanamkan hakihat sains sebagai salah satu bagian yang tidak terpisahkan (Chodijah, 2016). Bahan ajar yang dikembangkan dalam penelitian ini adalah media audio visual, yang berbentuk video pembelajaran dari hasil penelitian.

Salah satu media yang digunakan dalam pembelajaran, dan diyakini dapat lebih menggairahkan animo mahasiswa dalam perkuliahan adalah media audio visual. Media audio visual juga merupakan salah satu sarana alternatif dalam melakukan proses pmbelajaran berbasis teknologi. Media audio visual merupakan sarana alternatif dalam mengoptimalkan proses pembelajaran karena : a) mudah dikemas, b) lebih menarik dan c) dapat diperbaiki setiap saat (Haryoko, 2009).

Media audio visual diartikan sebagai media perantara atau penggunaan materi dan penyerapannya melalui pandangan dan pendengaran sehingga membangun kondisi yang dapat membuat mahasiswa mencapai kemampuan berpikir kreatif. Penerapan pembelajaran berbasis penelitian bakteri lipolitik pendegradasi limbah cair kelapa sawit dengan media audio visual diharapkan menjadi alternatif dalam menciptakan pembelajaran Mikrobiologi yang mengacu pada aspek proses, produk dan sikap ilmiah, dan dapat meningkatkan kemampuan berpikir kreatif mahasiswa.

Sampel yang digunakan dalam penelitian ini dapat diperoleh dari limbah pabrik pengolahan minyak kelapa sawit. Limbah cair ini lebih populer dikenal sebagai Palm Oil Mill Effluent (POME) (Agustina dkk, 2016). POME bersifat tidak beracun, tetapi tingginya kandungan zat organik menyebabkan nilai Chemical Oxygen Demand (COD), Biological Oxygen Demand (BOD) dan Total Suspended Solid (TSS) juga masih tinggi, sehingga akan mengganggu keseimbangan ekosistem jika dibuang langsung ke lingkungan (Rahmawati dan Azizah, 2005). Pencemaran lingkungan yang diakibatkan limbah cair pabrik kelapa sawit dikategorikan sebagai pencemaran lingkungan yang sangat serius, karena karakteristik limbah cair tersebut mengandung minyak lemak yang cukup tinggi berkisar 190-14.720 mg/L (Ditjen PPHP, 2006). Sedangkan baku mutu yang ditetapkan oleh pemerintah RI melalui Keputusan Mentri Lingkungan Hidup No. 51 tahun 1995 pada lampiran B adalah nilai minyak lemak sebesar $25 \mathrm{mg} / \mathrm{L}$ (Kepmen Lingkungan Hidup, 1995).

Rambe dkk (2014) mengatakan
limbah cair kelapa sawit memiliki kandungan BOD sebesar $20.000-30.000$ $\mathrm{mg} / \mathrm{L}$ dan COD sebesar 40.000 - 60. 000 $\mathrm{mg} / \mathrm{L}$, padatan tersuspensi dan terlarut, yang merupakan bahan anorganik dengan konsentrasi yang tinggi. Limbah ini dapat menjadi media pertumbuhan bakteri. Pemanfaatan bakteri yang hidup di limbah cair pabrik pengolahan kelapa sawit ini dapat dijadikan salah satu solusi untuk mengatasi pencemaran yang terjadi, karena selain prosesnya yang bersifat ekonomis dan efektif, bakteri tersebut juga banyak tersedia di alam untuk dimanfaatkaan sebagai agen biodegradasi (Wahyono dkk, 2011).

Bakteri yang didapat secara alamiah dilakukan dengan mengisolasi limbah itu sendiri, sehingga akan didapatkan bakteri yang indigenus, kemudian dikultur secara murni di dalam laboratorium dengan in vitro. Bakteri yang potensial akan diperbanyak, untuk selanjutnya dipakai sebagai isolat dalam pengolahan limbah. Kegiatan penelitian bakteri lipolitik indigen pada sampel bakteri yang terdapat pada limbah minyak pabrik pengolahan kelapa sawit, diharapkan dapat memberi manfaat sebagai sumber belajar mikrobiologi dengan bioteknologi. 


\section{METODE PENELITIAN}

\section{Subjek Penelitian}

Lokasi penelitian bertempat di Universitas Bengkulu dengan objek penelitian terdiri dari 72 orang mahasiswa S1 Biologi FMIPA, yang sedang mengambil mata kuliah Mikrobiologi. Pelaksanaan penelitian dilakukan pada bulan FebruariMei 2018.

\section{Metode dan Desain Penelitian}

Penelitian ini termasuk penelitian pengembangan bahan ajar yang diadaptasi dari model penelitian pengembangan pendidikan Thiagarajan (Thiagajaran dkk, 1974). Alasan pemilihan model pengembangan Thiagarajan adalah karena metode ini dapat menjabarkan sebuah strategi pengembangan produk pendidikan, dengan tujuan utamanya adalah untuk menemukan pengetahuan yang baru dari hasil penelitian yang dilakukan.

\section{Tahap Pendefinisian (define)}

Tahap pendefinisian dilakukan untuk menentukan syarat yang dibutuhkan pada pembelajaran. Tahap ini menggunakan metode deskriftip yang diawali dengan studi pustaka untuk mengumpulkan informasi mengenai mata kuliah mikrobiologi dalam batasan materi pokok bakteri, sehingga didapatkan gambaran fakta dan alternatif penyelesaian masalah untuk menentukan media pembelajaran yang dkembangkan. Dalam tahapan ini meliputi kegiatan (a) analisis materi pembelajaran, (b) analisis konsep dan (c) analisis Tujuan Pembelajaran

\section{Tahap Perencanaan (design)}

Rancangan (design) bahan ajar yang akan dikembangkan adalah media audio visual berbasis penelitian bakteri lipolitik pendegradasi limbah cair pabrik pengolahan kelapa sawit. Langkah-langkah dalam tahapan desain adalah : (a) membuat script awal mengenai tayangan materi pembelajaran yang akan divideokan agar video tampak menarik, (b) kegiatan yang akan divideokan atau difilmkan adalah tahapan kegiatan dalam riset sains laboratorium.

\section{Desain video pembelajaran}

Desain video pembelajaran terdiri dari pendahuluan. Pada bagian pendahuluan memuat video tentang banyaknya pencemaran lingkungan yang disebabkan oleh limbah cair pabrik pengolahan kelapa sawit. Pada bagian isi video memuat semua tahapan kerja dalam riset sains laboratorium tentang peranan bakteri lipolitik dalam mendegradasi limbah cair pabrik minyak kelapa sawit, yang terdiri dari : (1)Pengambilan sampel (2) Proses pengenceran sampel (3) Isolasi bakteri (4) Purifikasi bakteri lipolit (5) Uji aktifitas bakteri lipolitik (6) Uji Biokimia (7) Identifikasi isolat potensial secara makroskopis, mikroskopis, dan DNA molekuler. Bagian penutup dari video pembelajaran ditutup dengan kesimpulan dari pembelajaran dan informasi kepada mahasiswa bahwa mikroorganisme yang ada di lingkungan dapat dimanfaaatkan bagi kehidupan, baik untuk pangan, industri, kesehatan dan bioremediasi.

\section{Tahap pengembangan (develop)}

Tahap ini dilakukan pengukuran terhadap kelayakan media audio visual, yang akan digunakan. Bertujuan untuk menghasilkan media pembelajaran yang berorientasi pada berpikir kreatif. Bahan ajar yang akan digunakan divalidasi oleh (1) ahli media, (2) ahli IT dan (3) praktisi pendidikan, yaitu dosen pengampu matakuliah Mikrobiologi. Validasi meliputi komponen kelayakan isi, kebahasaan, sajian dan kejelasan suara narator.

Soal yang akan digunakan untuk mengukur keterampilan berpikir kreatif mahasiswa biologi divalidasi oleh guru besar biologi. Uji coba kelompok kecil diberikan kepada 20 orang mahasiswa S-1 Biologi FMIPA UNIB, yang sudah mengambil mata kuliah mikrobiologi. Hasil dari uji coba ini untuk melihat interpretasi validitas, reliabilitas dan tingkat kesukaran soal. Data yang diperoleh akan digunakan untuk penelitian lebih lanjut.

\section{Tahap Penyebaran (disseminate)}

Tahap penyebaran bahan ajar media audio visual yang sudah di validasi dan direvisi hanya terbatas pada mahasiswa $\mathrm{S}-1$ Biologi FMIPA UNIB Semester 4 dalam mata kuliah Mikrobiologi konsep 
mikroorganisme pokok bahasan bakteri lipolitik

\section{Analisis dan Interpretasi Data}

Teknik analisis data yang dilakukan menggunakan deskriptif kuantitatif yaitu memaparkan produk media hasil penelitian dalam bentuk audio visual, menguji tingkat validasi dan kelayakan produk untuk diimplementasikan pada mata kuliah mikrobiologi. Data yang bersifat komunikatif akan diproses untuk dijadikan bahan ajar, dengan adanya uji persetujuan. Hasil validasi dan persetujuan dapat dituliskan dengan rumus sebagai berikut :

Validasi kelayakan media

$\%$ kelayakan $=\frac{\text { skor yang diobservasi }}{\text { Skor yang diharapkan }} \times 100 \%$

Data yang terkumpul dianalisis dengan teknik analisis deskriptif kuantitatif yang diungkapkan dalam distribusi skor dan persentase terhadap kategori skala penilaian yang telah ditentukan. Setelah penyajian dalam bentuk persentase, langkah selanjutnya mendeskriptifkan dan mengambil kesimpulan tentang masingmasing indikator. Kesesuaian aspek dalam media pembelajaran yang dikembangkan menggunakan tabel berikut :

Tabel : 1 Kriteria validasi media (Sudjana, 2005)

\begin{tabular}{cll}
\hline Interpretasi & Persentase & Kriteria \\
\hline A & $80-100 \%$ & Valid \\
B & $60-79 \%$ & Cukup Valid \\
C & $50-59 \%$ & Kurang Valid \\
D & $<50 \%$ & Tidak Valid \\
\hline
\end{tabular}

\section{Kemampuan Berpikir Kreatif}

Data skor pre-test dan post-tes dianalisis dengan menghitung mean dari pretest dan post-test, kemudian dilakukan perhitungan N-Gain menurut rumus dari Hake (Savinem \& Scott, 2002). Penggunaan rumus tersebut dilakukan untuk mengetahui tingkat berpikir kreatif mahasiswa yang dijaring melalui pre test dan post test.

$$
\begin{array}{ll}
g & =\frac{(\text { s post }- \text { s pre })}{(\text { s max }-s \text { pre })} \times 100 \\
& \text { Keterangan : } \\
\mathrm{g} & =\text { skor peningkatan } \\
\text { s post } & =\text { skor tes akhir } \\
\text { s pre } & =\text { skor maksimum } \\
\text { s max } & =\text { skor maksimum }
\end{array}
$$

Tabel : 2 Kriteria Gain berpikir kreatif

\begin{tabular}{lll}
\hline No & Perolehan & Skor \\
\hline 1 & $\mathrm{G}<0,3$ & Rendah \\
2 & $0,3 \leq 0,7$ & Sedang \\
3 & $\mathrm{G}>0,7$ & Tinggi \\
\hline
\end{tabular}

\section{HASIL DAN PEMBAHASAN}

Video pembelajaran yang didapat dari hasil penelitian ini digunakan untuk mengukur tingkat berpikir kreatif mahasiswa dilihat dari 4 komponen yang dijabarkan dalam indikatorindikator berpikir kreatif, yaitu fluency, flexibility, original dan elaboration. Penjabaran indikator ini membahas tentang pengajuan masalah dan pemecahan masalah yang akan dijadikan pedoman untuk membuat rancangan pre-tes dan pos-tes berpikir kreatif. Perangkat pembelajaran, seperti SAP, soal pre tes dan pos tes serta video pembelajaran yang digunakan divalidasi oleh tim ahli

\section{Validasi SAP}

Validasi SAP oleh praktisi pendidikan, yang dalam hal ini adalah dua orang dosen pengampu mata kuliah mikrobiologi Universitas Bengkulu. Hasil validasi dilanjutkan dengan analisis data, dan revisi produk berdasarkan review para ahli tersebut. Setiap aspek dari SAP dihitung rata-rata skor yang didapat, dari keempat aspek penilaian oleh panelis memiliki skor dengan kategori baik, Rata-rata nilai capaian untuk satuan acara perkuliahan (SAP) sebesar 78,8\%. Dari skor yang diperoleh menunjukkan bahwa SAP yang dibuat sesuai dengan silabus, SK, KD materi dan tujuan dari pembelajaran yang ada. Grafik validasi SAP oleh panelis dapat dilihat pada Gambar 1.

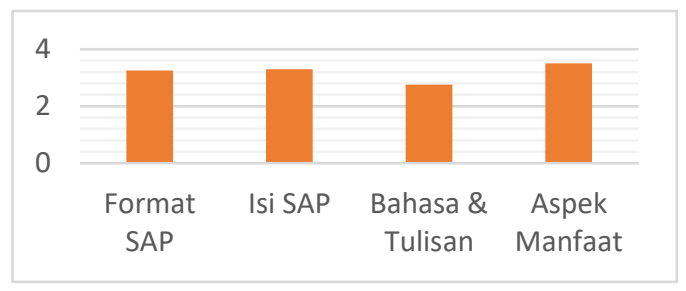

Gambar 1. Grafik validasi SAP

\section{Validasi Video Pembelajaran}

Pengembangan media pembelajaran ini meliputi membuat, mengembangkan, memodifikasi dan melakukan uji coba video 
pembelajaran. Tahap pengembangan ini merupakan penjabaran dari desain dan dibuat berdasarkan atas teknik yang dilakukan dalam penelitian dan hasil penelitian. Hasil pengembangan bahan ajar ini, selanjutnya divalidasi oleh praktisi pendidikan, ahli media pembelajaran dan ahli IT. Hasil validasi ketiga tim ahli didapatkan nilai ratarata $82,13 \%$, dengan beberapa bagian produk mengalami revisi hingga dikatakan video pembelajaran yang dihasilkan layak untuk digunakan. Grafik validasi Video pembelajaran dapat dilihat pada Gambar 2. Berdasarkan Sudjana (2005) nilai capaian $82,13 \%$ masuk dalam nilai interpretasi A dengan kriteria valid dan dapat diuji cobakan di lapangan.

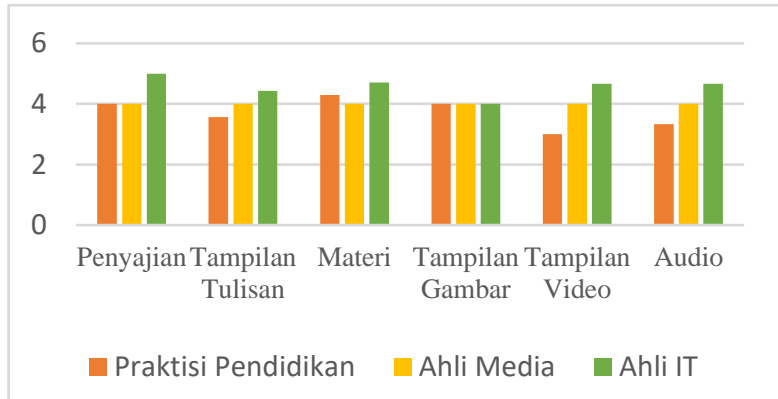

Gambar 2. Grafik validasi video pembelajaran

\section{Soal Berpikir Kreatif}

Rubrik soal berpikir kreatif yang digunakan divalidasi oleh guru besar Biologi, hasil validasi mendapatkan kriteria penilaian baik dengan nilai $82 \%$. Soal uji skala kecil setelah divalidasi akan digunakan pada uji coba lapangan untuk mengetahui tingkat kemampuan berpikir kreatif mahasiswa. Hasil uji validitas, reliabilitas, tingkat kesukaran dan daya pembeda soal yang baik, maka instrumen tes hasil belajar tersebut dapat digunakan sebagai alat pengumpul data. Soal yang telah diuji cobakan ini kemudian dapat digunakan sebagai alat ukur penelitian untuk melihat keberhasilan dalam meningkatkan kemampuan berpikir kreatif mahasiswa. Sebelum melakukan pembelajaran di kelas 72 orang mahasiswa tersebut diberikan pre-tes untuk mengetahui kemampuan awal mahasiswa terhadap materi yang akan disampaikan. Selanjutnya pembelajaran di kelas dilakukan sesuai dengan materi pembelajaran yang telah dideskripsikan pada Satuan Acara Perkuliahan (SAP). Pada akhir pembelajaran objek diberikan kembali pos-tes yang berguna untuk melihat kemampuan akhir dari mahasiswa.

Tingkat berpikir kreatif mahasiswa S-1 Biologi FMIPA UNIB semester 4 dilihat dari indikator yang ada yaitu lancar (fluency), luwes (flexibility), orisinil (original), dan elaborasi (elaborasi) (Facione, 2013), yang diukur dari hasil pencapaian tes soal berpikir, menunjukkan adanya peningkatan (Gambar 3)

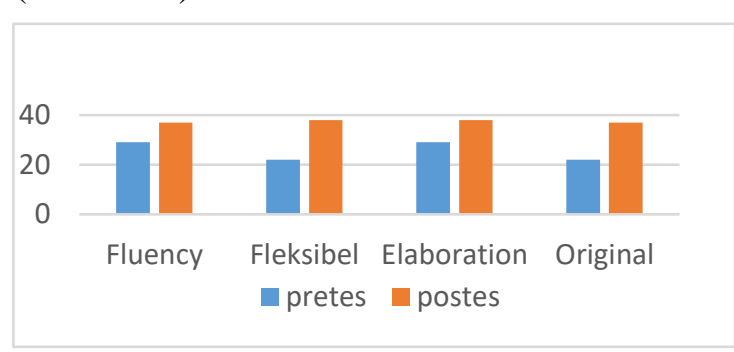

Gambar 3. Grafik hasil pretes dan pos tes

Data tersebut menunjukkan bahwa nilai pos-tes yang didapat dalam pembelajaran pada setiap indikator berpikir kreatif lebih tinggi dibandingkan pre-tes. Hal ini mengindikasikan bahwa mahasiswa sebagian besar memahami konsep dasar mengenai materi yang diberikan, sehingga dari segi kedalaman materi dapat diserap dengan baik.

\section{KESIMPULAN}

Hasil implementasi pendidikan secara keseluruhan terhadap 72 orang mahasiswa tingkat kemampuan berpikir kreatifnya terdiri dari 9 orang masuk dalam kategori tinggi $(12,5 \%), 51$ orang kategori sedang $(70,8 \%)$ dan 12 Orang masuk dalam kategori rendah $(16,7 \%)$. Perhitungan ini mengarah pada perhitungan $\mathrm{N}$-Gain (Savinem dan Scott, 2002). Dari kriteria perhitungan NGain ini dapat dirata-ratakan bahwa kemampuan berpikir mahasiswa S-1 Biologi FMIPA UNIB semester 4 masuk dalam kategori sedang.

\section{DAFTAR PUSTAKA}

Agustina, T. E., Sulistyono, B., \& Anugerah, R. (2016). Pengolahan Palm Oil Mill Effluent (Pome) Dengan Metode Fenton Dan Kombinasi AdsorpsiFenton. Jurnal Teknik Kimia, 22(3). 
Chodijah, S. (2016). Analisis Pelaksanaan Praktikum Pada Pembelajaran Biologi Siswa Kelas Viii Di Smp Negeri 1 Seputih Raman Kabupaten Lampung Tengah Tahun Pelajaran 2015/2016.

Ditjen Pphp. (2006). Pedoman Pengelolaan Limbah Industri Kelapa Sawit. Subdit Pengelolaan Lingkungan Direktorat Pengolahan Hasil Pertanian. Departemen Pertanian.

Hamzah, A. (2014). Evaluasi Pembelajaran. Jakarta: Pt Raja Grafindo Persada

Haryoko, S. (2009). Efektivitas Pemanfaatan Media Audio-Visual Sebagai Alternatif Optimalisasi Model Pembelajaran. Jurnal Edukasi Elektro, 5(1).

Keputusan Menteri Lingungan Hidup No. 51 Tahun 1995 Tentang Baku Mutu Limbah Cair Bagi Kegiatan Industri.

Rahmawati, A. A., \& Azizah, R. (2005). Perbedaan Kadar Bod, Cod, Tss, Dan Mpn Coliform Pada Air Limbah, Sebelum Dan Sesudah Pengolahan Di Rsud Nganjuk. Jurnal Kesehatan Lingkungan, 2(1).
Rambe S.M, Iriany, Irvan (2014). Pengaruh Waktu Tinggal Terhadap Reaksi Hidrolisis Pada Pra-Pemuatan Biogas Dari Limbah Cair Kelapa Sawit, Jurnal Dinamika Penelitian, Usu, Medan.

Savinem, A \& Scott, P. (2002). "The Force Concept: A Tool For Monitoring Student Learning". In Physics Education. 39 (1), 45-42.

Sudjana.N, (2005). Penilaian Hasil Proses Belajar Mengajar. Bandung: $\mathrm{Pt}$ Remaja Rosdakarya.

Thiagarajan, S., Semmel, D.S., And Semmel, M.I.. (1974). Instructional Development For Training Teachers Of Exceptional Children. Washington: National Center For Improvement Of Educational.

Wahyono, S., Si, S., Si, M., Sahwan, I. F. L., Si, M., \& Suryanto, F. (2011). Membuat Pupuk Organik Granul Dari Aneka Limbah. Agromedia. 